\title{
DUAL MONETARY INSTRUMENTS' IMPACT ON THE PERFORMANCE AND STABILITY OF JAKARTA ISLAMIC INDEX
}

\author{
Bazari Azhar Azizi 1
}

\begin{abstract}
The monetary instruments and capital market are closely related as these tools are operating in the money market. The influence of the monetary policy to the stocks and indexes' performance has been the research interest in the previous literature. The monetary policies along with its' instruments are transmitted not only in banking lending channel to affect the economic growth but also in the balance sheet channel. However, the conventional tools and policies are not adhering the sharia tenets. Hence, the shariacompliance monetary system is emanated in Muslim majority countries, including Indonesia. Additionally, this establishment of policy is coupled with the emergence of the Islamic capital market in Indonesia. Thus, the analysis of the impact of either Islamic or conventional monetary system on the Islamic capital market in Indonesia that represented by the Jakarta Islamic Index (JII) is essential to look at its' furthers effect on financial market growth. This study examines the impact of the Islamic and conventional monetary variables on the performance of the Jakarta Islamic Index in Indonesia. It also investigates the stability of the $\mathrm{Jl}$ under the occurrence of the shock derived from the monetary instruments. Monthly closing value of the $\mathrm{JII}$, conventional or interest rate, Islamic policy rate, and monetary base are assessed to address the research objectives in this paper. This study employs the VAR-VECM and Granger analysis to analyse the phenomenon. The monetary policy transmission mechanism through the financial market channel is the main channel that will be investigated in this paper. The study comprises of introduction, literature review, methodology, and lastly the discussion and conclusion.
\end{abstract}

Keywords: Dual monetary policy, VAR-VECM, JII

JEL Classification: E52, E44, E47

Received: September 19, 2017; Revised: January 1, 2018 ;

Accepted: January 15, 2018

1 Affiliation: MSc Islamic Finance Student Durham University Business School, Email bazari91@gmail.combazari@durham.ac.uk. 


\section{INTRODUCTION}

The Islamic capital market, as one of Islamic finance sectors, is accounted for the vast amount of funds invested. Recently, this market comprises of $\$ 342$ billion outstanding sukuk and $\$ 66$ billion Islamic funds globally with average growth of 14 and 15 percent respectively (Reuters, 2016). This distinct market applies sharia-compliance screening mechanism, which inhibits investing in several sectors (Ajmi, Hammoudeh, Nguyen, \& Sarafrazi, 2014). Additionally, it also contributes largely to intermediating funds and offers alternate channels for investment and financing as it enables mobilisation of economic resources regardless of the prohibition or screening process (Malini \& Jais, 2014). Furthermore, Sharia-compliance stocks are proven to be more resilient during the financial crisis in comparison with conventional (Pranata \& Nurzanah, 2015). From this fact, Indonesia as a growing Muslim market, attempt to provide and develop Islamic finance industry including Islamic capital market.

Notwithstanding the potential of the infant Islamic stocks market, as well as the conventional counterpart, it is primarily correlated with economic and financial milieu domestically and globally. In conventional monetary concept, the increasing interest rate initiates the adverse correlation of interest rate and share prices (Maysami \& Koh, 2000). Moreover, in the emerging economy, the adjustment of central bank's interest rate induces negative perception in the market (Wahyudi \& Sani, 2014). Thus, the central bank's monetary instrument can affect the economic operation including capital market from this theory or known as monetary transmission mechanism (Mishkin, 2004). Henceforth, the central bank is obliged to consider the capital market performance as its essentiality in enhancing the economic growth. However, the typical monetary instruments are interest-based in which contravene the sharia ruling on the prohibition of riba, and thus alternative tools of monetary policy emerge with the profit-sharing, margin or fee as their base (Ascarya, 2012). Indonesia, a country that implements a dual system of financial architecture, establishes the Islamic financial system to cope with the conventional industry, including the Islamic capital market and Islamic monetary system together with its instruments. Nevertheless, the research on this particular subject is still inadequate.

The analysis on the market returns and economic variables that might influence its performance discussed earlier by Fama and Schwert (1977) through the examination of the correlation of the asset returns and inflation. Their discussion further extended in the study conducted by Fama 
(1981) and Fama and Gibbons (1982) that analyse stock returns with specific economic variables including inflation, real activity, and correlation with the quantity of money demanded theory for the former. The latter explains expected and unexpected inflation, real returns, and capital investment that could affect the performance of stocks. However, these previous researchers do not specify in which category of the variable that stocks' performance is determined. Hence, Geske and Roll (1983) conduct investigation on the fiscal and monetary linkage with the stock market returns. In response to this analysis, several studies attempted to furtherly examine the emergence of a phenomenon that portraying the monetary instruments that can affect the stock prices or performance. These studies are conducted by James et al. (1985), Friedman (1988), Lee (1992), Thorbecke (1997), Durham (2003), and Rigobon and Sack (2003). Additionally, the recent analysis performed by Hojat (2015) examines the monetary policy instruments' impact on the capital market. However, their findings vary concerning the monetary variables effect to the stock markets, whereby some note the negative influence of these variables while others convey the presence of positive feedback.

Albeit the significance of these studies, however, their analysis is focused on the developed market although the capital markets are not only flourishing in advanced economies, but also in the emerging ones. Ibrahim (2001) began to expand the discussion on monetary policy and stock market returns in an emerging market through the stability evaluation during the shocks on the system. His analysis then continued by Hooker (2004) by looking at to not only the monetary variables but also a macroeconomic state of emerging market towards their stocks' market performance. However, these studies neglect the analysis on Islamic capital markets that appeared in the 1990s although this market offers diversification alternatives in investment and provides sharia-compliance stocks. Hence, Hakim and Rashidian (2002) performed analysis on Islamic capital market risk and return, along with the possibilities of linkage between the conventional and Islamic market. The next study from Yusof and Majid (2007) and Albaity and Ahmad (2008) compare the performance of both markets instead of assessing the mere nexus of the markets with study case in Malaysia. Furthermore, the relationship between macroeconomic variables and Islamic stock markets' return is investigated by Majid and Yusof (2009). Furthermore, it is expanded by Krasicka and Nowak (2012), Ajmi et al. (2014), Rana and Akhter (2015) and recently Bahloul et al. (2017). 
Nevertheless, these studies are primarily attempted to investigate the Malaysian or global Islamic capital market. In fact, the Islamic capital market is not only developed in these markets but also in Indonesia since 2000. Moreover, aside from Malaysia, Indonesia implements Islamic monetary policy to transmit its instruments to the Islamic stocks market (Ascarya, 2014). The market in two mentioned countries is not only moving together but also reveals the similar growing movements as portrayed in the following Figure.

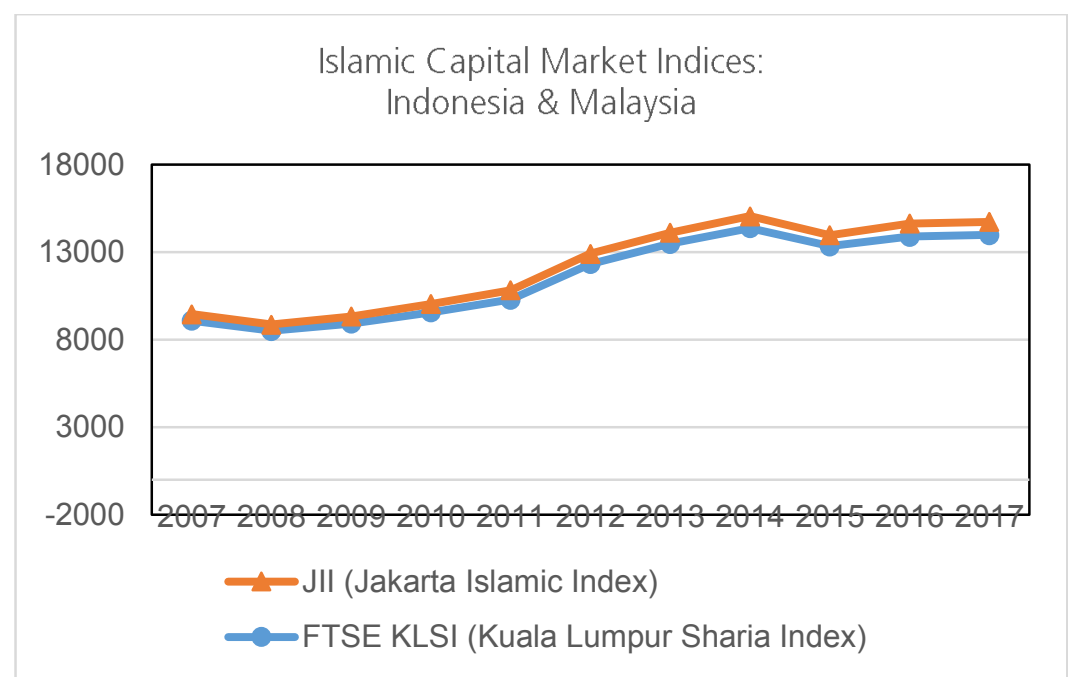

Source: Thomson Reuters (2017)

Figure 1.

Indonesia and Malaysia Islamic Capital Market Indices Movement

Therefore, several recent studies conduct analysis on Indonesia Islamic capital market that began with Malini and Jais (2014). They assess the conventional macroeconomic variables' effect towards market volatility. Meanwhile, Wahyudi and Sani (2014) concentrate on the interdependence of Islamic market with money market variables whereas Pranata and Nurzanah (2015) furtherly investigate the performance of the conventional and Islamic market in Indonesia along with their determinants, including conventional monetary policy. Nonetheless, these studies still lack on analysing the comparison of the determinant factors of Indonesian Islamic capital market, especially the Islamic monetary policy. The meticulous research should be conducted since Indonesia implement both Islamic and conventional monetary policy. These policies are transmitted through Islamic and conventional capital market in monetary transmission mechanism process. Hence, this study will examine the positive or negative 
significant influences of the implementation of Islamic and conventional monetary policy towards the sharia compliance stock performance in Jakarta Islamic Index (JII). Moreover, the stability of the JII under the occurrence of the shocks in monetary variables will be measured in this study.

\section{LITERATURE REVIEW}

\subsection{Monetary Policies and Transmission Mechanism}

Ismail (2010) defines the monetary policy as operations conducted by the central bank to affecting the money supply and advancing economic targets including price stability and sustainable growth. This policy has three essential tools including the interest rate, the open market operation, and the reserve requirement ratio (Mishkin, 2004). However, Uthman (2005) argues that implementing the interest rate system will segregate the financial and real sectors that furtherly triggers disequilibrium and decoupling situation in the financial intermediation process (Askari, lqbal, \& Mirakhor, 2015). Rab and Hifzur (2006) also emphasise the inability of interest rate practice to maintain monetary stability due to money creation issue. Moreover, Uthman (2005, p. 219) conveys the fractional reserve inhibits 'inherent instability' and thus it contains complexity in conducting monetary policy. Therefore, the alternative policy is awaited to resolve all above issues from the conventional system, and Islam provides other alternate solutions.

Following the above issues, Chapra (1985) illustrates the Islamic monetary theory and concept within several hypotheses. First, the prohibition of interest-based assets and promoting profit-loss-sharing will strengthen the economy. Second, the elimination of interest system would reduce the speculative money demand and convey more stability to the total money demanded and the business cycle. Third, the central bank should align their policy with the monetary base to satisfy financing needs and spur socio-economic growth. Thus, from these assumptions, Uthman (2005) suggests three Islamic monetary policy mechanisms. These are substituting the interest-based with the profit-sharing system (Chapra, 1985), implementing 100 per cent reserve banking system (Askari et al., 2015), and replacing the discount rate with 'sovereign profit sharing (SPS).'

In implementing the above policies to the economic sector, including financial market, the transmission mechanism of monetary policies' theory explains the process of it. The monetary policy transmission channels that 
relate to the stock market and prices are a traditional interest-rate channel (Mishkin, 2004), Tobin's q theory (Tobin, 1969), wealth effect, balance sheet channel (Modigliani, 1971), and household liquidity effect (Mishkin, 2004). These are the conventional channels of the monetary transmission mechanism. Ascarya (2012) assert the similarity of the Islamic monetary policy transmission process with the conventional due to the resemblance in some instruments.

Nonetheless, the Islamic monetary policy transmission mechanism has different features from it natures. The profit-sharing rate application stimulates the different amount of return based on the economic performance (Sukmana \& Kassim, 2010). Additionally, while the conventional monetary policy focuses on controlling the money supply in the money market, the Islamic policy controls the money supply through Islamic banks and capital market through the 'Islamic pass-through rate' (Ascarya, 2012). Furthermore, Ascarya (2014, p. 12) convey that Islamic monetary policy can be transmitted through profit and real sector channel as its distinctive feature. Hence, these differences will affect the Islamic capital market and economic condition differently than the conventional monetary policy transmission (Askari et al., 2015).

\subsubsection{Indonesian Dual Monetary Policy and Transmission Mechanisms}

Indonesia operates dual monetary policies of both Islamic and conventional. It contains different instruments as compared to the conventional (Ascarya, 2014). The instruments and tools of each purpose as explained in Table below.

Table 1.

Dual Monetary Policy and Instruments in Indonesia

\begin{tabular}{|c|c|c|c|}
\hline Purpose & Instrument & Conventional & Islamic \\
\hline $\begin{array}{l}\text { Fractional Reserve } \\
\text { Banking }\end{array}$ & $\begin{array}{l}\text { Statutory Reserve } \\
\text { Requirement }\end{array}$ & \multicolumn{2}{|c|}{ Reserve Requirement } \\
\hline \multirow[t]{2}{*}{$\begin{array}{l}\text { Lender of the } \\
\text { Last Resort } \\
\text { (Standing } \\
\text { Facilities) }\end{array}$} & Lending Facilities & $\begin{array}{ll}\text { - } & \text { STFF; - ILF } \\
\text { - } & \text { Repurchase } \\
& \text { agreement (Repo) } \\
\text { of SBI }\end{array}$ & $\begin{array}{l}\text { - SSTFF; - SILF } \\
\text { - Repo of SBIS/SBSN }\end{array}$ \\
\hline & Deposit Facilities & FASBI (1-day) & FASBIS (1-day) \\
\hline Regular Monetary & Open Market & - SBI (1-12 month) & - SBIS (1-12 month) \\
\hline Policy & Operation (OMO) & - TD (1-12 month) & - Reverse Repo SBSN \\
\hline
\end{tabular}


The primary instruments for Indonesia's dual monetary policy are Bank Indonesia Certificate (SBI) and Bank Indonesia Islamic Certificate (SBIS) for conventional and Islamic policy respectively. The SBI is a certificate issued by the Central Bank of Indonesia (Bank Indonesia) as an acknowledgement of short-term debt from the central bank, which employs the interest rate and used as Bank Indonesia's policy rate to transmit the monetary policy. Meanwhile, before the SBIS, Indonesia implemented Bank Indonesia Wadiah Certificate (SBWI) by employing wadiah contract as its foundation. Akin to SBI, SWBI indicates short-term funds' placement in Bank Indonesia, with additional bonuses paid-off at the maturity based on Indonesian Interbank Islamic Money Market return. Both instruments issued to attract extra liquidity (Wahyudi \& Sani, 2014) at the money market, while SWBI's fee and SBI's rate are 'policy rate' (Ascarya, 2012).

However, since SWBI demonstrated several drawbacks, it was converted to the SBIS by utilising jualah contract starting from April 2008. With these two instruments (SBIS and SBI), Bank Indonesia can affect banks' financing and funding tendencies through the interbank money markets, in either conventional money market (PUAB) or Islamic money market (PUAS), and eventually influence the cost of funds and financial assets price. Hence, Ascarya (2012) proposes a conceptual framework of dual monetary policy transmission mechanism for conventional and Islamic by employing Granger causality method, which further expanded by Wahyudi and Sani (2014) in Figure below.

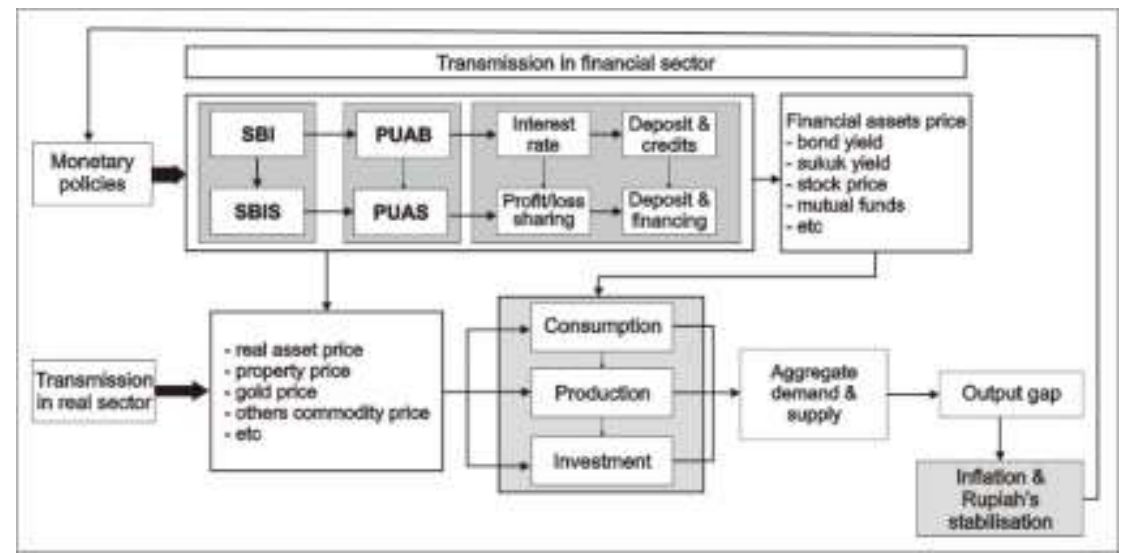

Source: Wahyudi and Sani (2014, p. 36)

Figure 2.

Dual Monetary Transmission Mechanism in Indonesia 
From the above Figure, monetary policy transmission mechanism in the financial sector of Indonesia occurs through interest rate or profit/loss sharing channel. Adjustments in monetary policy are followed by changing the monetary instruments (SBI and SBIS), then affecting the PUAB or PUAS return, and finally altering the financial assets price (Wahyudi \& Sani, 2014). The significance of this concept should be examined, and the following part elaborates this in several empirical studies.

\subsection{Previous Studies}

The initial study is conducted by Fama and Schwert (1977) by examining the Fisher theory (1896) that the interest rate is positively correlated with the stock markets. They found the opposite result from the multivariate regression results on the New York Stock Exchange (NYSE). It conveys the negative relations between the common stocks' return to the expected inflation proxied by the interest rate, and this result expresses different concept from Fisher.

The above finding is expanded by Fama (1981) with additional economic determinants of stock returns comprising expected, unexpected inflation rate, and the monetary base (M2). His analysis implies consistent negative impact of the inflation rate to the stock returns. Furthermore, this adverse effect is only occurred with the inclusion of money base growth rate in the regression model, due to the presence of high correlation between the expected inflation rates with money. This result shows that both expected inflation and $\mathrm{M} 2$ are negative determinants of stock returns. Fama and Gibbons's (1982) analysis support these findings. These three preceding studies reveal the presence of interest rate and stocks return's puzzle. However, Geske and Roll (1983) questions the Fama and Schwert's (1977) findings that contravenes the Fisher's theory. Hence, they conduct a comprehensive analysis of the linkage between the fiscal and monetary variables with the stocks return by extending the work of Fama (1981). Nonetheless, their result demonstrates the presence of the significant negative signal of real interest rate to the stock returns which contradict their initial hypothesis.

Then, James et al. (1985) comment two rationales behind this contradiction namely the inappropriate equation system and the restriction of other possible causal relationship. Thus, they correspond this through investigating inflation, money supply, real activity, and stock returns using a vector autoregressive moving average (VARMA) to acquire the causal 
relations among potential variables. Their findings reveal additional empirical result by showing negative and significant $M 2$ growth effect on stock returns. Furthermore, Friedman's (1988) analyses response James et al.'s result with similar variables except for money velocity. His finding implies the positive relation between $\mathrm{M} 2$ and deflated stock prices in which indicating a wealth effect, while $M 2$ is negatively affecting the current price that reflecting substitution effect. Moreover, the wealth dominates over the substitution effect. Hence, this finding for M2 akin to Thorbecke (1997) result that exhibits a positive correlation between money growth and expansion to the real stock returns.

Additionally, Lee (1992) proves that only little variation in inflation is explained by stock returns with the presence of interest rate in Vector Autoregression (VAR) system. Hence, his finding reveals that no causality present between $\mathrm{M} 2$ and stock returns, which contrasting James et al. (1985) result. Furthermore, studies conducted by Durham (2003), and Rigobon and Sack (2003) attempt to focus on analysing the monetary policy and the stock market, but they differ in the result. Durham's (2003) research reveals that the relationship between the monetary policy and stock return are weak. However, this assertion is opposed by Rigobon and Sack (2003). By employing VAR method, they reveal that to determine factors affecting the stock market, the interest rate movement as a monetary variable must be considered. Besides, their finding demonstrates the occurrence of shock affect the covariance of interest rate and stock prices. Hence, it proves stock prices and the interest rate correlation, while recognising the endogeneity problem among monetary policy variables and the stock market as well. The more recent study conducted by Hojat (2015) supports Rigobon and Sack findings and asserts that these monetary variables should be considered to prevent the market crash.

The previous studies investigate more on the developed market while giving less attention to the emerging economies, although the capital market operates in these countries and the share prices' movement may differ (Majid \& Yusof, 2009). Ibrahim (2001) initiates the study on an emerging capital market and the influence of monetary policy shocks towards its return. He focuses on evaluating $\mathrm{M} 2$ and the equity returns. His analysis denotes that $\mathrm{M} 2$ is dominantly explaining emerging market variation compared to others. Hence, a unidirectional causation appears between money supply and stock prices. Additionally, Hooker (2004) extends this study by combining macroeconomic and monetary factors on the emerging stock market's performance utilising Bayesian model 
selection. His findings demonstrate these variables have a negatively significant influence on the market's return. Therefore, these two cases indicate the persistence of monetary policy's effect on stock prices even though they are in the less sophisticated market.

While more attention given to the developed and developing economies' capital market, these previous studies exclude Islamic equity markets due to the latter development occurs in this market. Different findings may arise when assessing the determining variables affecting the Islamic capital market. Hakim and Rashidian (2002) initiate the study focusing on the sharia-compliance equity market. They examine the risk and return of Islamic and conventional equity indices along with the probability of the nexus of both markets and their relationship with the interest rate. The result stipulates the independence of the Islamic index return with the conventional counterpart and the interest rate. Thus, this result is in tandem with the sharia-tenet that prohibit riba in the financial market.

These results encourage Yusof and Majid (2007), Albaity and Ahmad (2008) to analyse the Islamic and conventional indices by investigating Malaysia's market. The former studies the transmission of the stock market instability of Islamic vis-à-vis conventional, while the latter compares the market's performance. Yosuf and Majid (2007) findings justify that the volatility of interest rate dissociates with Islamic market instability that is akin to Hakim and Rashidian's conclusion. Hence, the interest rate cannot be employed to stabilise Islamic stocks market. However, Albaity and Ahmad (2008) findings contravene with Hakim and Rashidian (2002) whereby the causal relation of Islamic and conventional market exists and advance similarly, either for the short or long-run. Similarly, Krasicka and Nowak (2012) accentuate the diminishing divergence between the Islamic and conventional financial market. Hence no significant disparity of wealth effect to the investors by investing in both markets (Albaity \& Ahmad, 2008).

Furthermore, Majid and Yusof (2009) analyse several macroeconomic variables including treasury bill and federal fund rate, money supply and exchange rate to evaluate Hakim and Rashidian findings. They examine the relationship in the short and long-run through autoregressive distributed lag (ARDL) model. Their findings imply that Malaysia's Islamic capital market and the investor's behaviour are not only affected by the domestic, but also global interest rate. Correspondingly, the VAR analysis of developed Islamic capital market by Ajmi et al. (2014) presents the same indication on the US 
Federal Funds Rate effect towards Dow Jones Islamic Market (DIIM). Hence, these facts infer the non-adherence towards the sharia tenets whereas Islamic capital market should not correlate with the interest rate.

Nevertheless, Rana and Akhter (2015) alongside Bahloul et al. (2017) reveal opposing results with two previous studies, while supporting Hakim and Rashidian's initial results. Firstly, Rana and Akhter (2015) study emphasise that the interest rate does not influence an emerging Islamic capital market. Their studies' result of Karachi Meezan Index (KMI) in Pakistan vis-à-vis Karachi Stock Exchange (KSE) and the impact of the interest rate volatility to both indices support their assertion. Secondly, by implementing Markov-Switching VAR (MS-VAR), Bahloul et al. (2017) reveal the interest rate does not explain the dynamics in either emerging or developed Islamic stock indices. Moreover, they demonstrate that these Islamic indices are affected by the money supply and conventional indices' return due to the benchmarking.

The previous research has been analysing the Islamic capital market in developed and developing economies with several case studies of emerging countries. These research, however, neglecting Indonesia as another jurisdiction that implementing sharia tenets in the capital market. Hitherto, few studies conducted to examine Indonesia's Islamic capital market and its determinants from monetary variables. Additionally, Indonesia implements Islamic monetary policy besides Malaysia to achieve output growth through monetary policy transmission mechanism. Hence, Ascarya (2012) initiates his research on the dual monetary policy effectiveness and its transmission channel in Indonesia by utilising VARVector Error Correction Model (VECM) and Granger causality analysis, where he found that the SBIS reduce inflation and spur the economic output. Consequently, Malini and Jais (2014) conduct their research on the interest rate as a monetary instrument, towards Islamic sharia-compliance index.

The VAR-VECM result of Malini and Jais (2014) reveals domestic and global interest rate, inflation, and exchange rate are negatively affecting the Indonesia's Islamic equity market. The inflation is negatively affecting the market that resembles Fama's (1981) findings, while the interest rate from Bank of Indonesia and the Federal Reserve indicates positive effect at the beginning of the period. Meanwhile, in the middle and long-term, it demonstrates negative impact on the Islamic market that is consistent with Fama and Schwert (1977). However, this result contradicts with the sharia injunction of usury or interest rate. Hence, Wahyudi and Sani (2014) 
hypothesise that the Indonesia Islamic capital market that reflected by the JII should not be affected by the SBI rate, but the SBIS rate. Their result through VAR-VECM analysis validates their premises although their Granger causality's outputs conclude differently. In fact, they convey that the Jll only influenced by the exchange rate and the volatility index.

To extend the above analysis, Pranata and Nurzanah (2015) analyse the JII and LQ45 as the current equivalent of Islamic capital market along with their determinants including exchange rate, Bank Indonesia's interest rate, the Federal reserve rate, inflation, production index, money supply, and oil price. Their ARDL and CAPM result imply three essential results. First, the $\mathrm{JI}$ and LQ45 are not significantly different from their performance. Second, the JII is less volatile than LQ45. Lastly, either domestic or global interest rate affect the $\mathrm{JII}$, which contravene the sharia tenets and contradict with the initial findings that of Hakim and Rashidian (2002).

The previous studies imply the conventional and Islamic monetary policies may influence the Islamic capital market distinctively. These literature reveal the analysis on the common monetary variable effect on the III has been conducted. The interest rate is believed to not affecting the Islamic capital market as conveyed by Yusof and Majid (2007), Abugri (2008), Wulandari (2014), and Rana and Akhter (2015). This phenomenon occurs due to the injunction of riba within Islamic finance system (ISRA, 2012). Meanwhile, according to the transmission process of monetary policy, the Islamic instruments should affect the Islamic capital market prices and hence their performance as implied in Wahyudi and Sani (2014). This notion emanates from profit-loss-sharing principle implementation of Islamic monetary system (Chapra, 1985). Lastly, the neutral variable of M2 can have a negatively significant impact on the Islamic capital market according to Fama (1981), James et al. (1985), Abugri (2008), and Rahman et al. (2009). Hence, these three initial assumptions and the respective instruments' influence should be evaluated to confirm the previous conflicting findings.

\section{DATA AND METHODOLOGY}

\subsection{Data}

This study opts for the secondary data and econometrical methods to analyse the phenomenon and answering the research objective. The study will engage with several types of data that are summarised in Table below. 
Table 3.

Data Description

\begin{tabular}{|c|c|c|c|}
\hline No. & Data & Source & Period \\
\hline 1. & $\begin{array}{l}\text { Jakarta Islamic Index (JII) } \\
\text { as the sharia compliance } \\
\text { stocks performance }\end{array}$ & $\begin{array}{l}\text { Thomson Reuters } \\
\text { DataStream }\end{array}$ & July 2000 to May 2017 \\
\hline 2. & $\begin{array}{l}\text { Bank Indonesia Islamic } \\
\text { Certificate (SBIS) rate as } \\
\text { an Islamic monetary } \\
\text { instrument in Indonesia }\end{array}$ & $\begin{array}{l}\text { the Central Bank of } \\
\text { Indonesia Statistics }\end{array}$ & July 2000 to May 2017 \\
\hline 3. & $\begin{array}{ll}\text { Bank } & \text { Indonesia } \\
\text { Certificate (SBI) rate as a } \\
\text { conventional monetary } \\
\text { instrument }\end{array}$ & $\begin{array}{l}\text { the Central Bank of } \\
\text { Indonesia Statistics }\end{array}$ & July 2000 to May 2017 \\
\hline 4. & $\begin{array}{l}\mathrm{M} 2 \text { is the amount of } \\
\text { money circulation in } \\
\text { Indonesia and a neutral } \\
\text { monetary policy } \\
\text { instrument }\end{array}$ & $\begin{array}{l}\text { the Central Bank of } \\
\text { Indonesia Statistics }\end{array}$ & July 2000 to May 2017 \\
\hline
\end{tabular}

From 2000, Jakarta Islamic Index (JII) is launched as the performance indicator of the Sharia-compliant stocks in Indonesian Islamic capital market. The Indonesian Stock Exchange (IDX) initiates the establishment of JII, which constitutes 30 most liquid Sharia-compliant stocks with large market capitalisation. It implements six months screening and reviews from the sharia stocks list published by the Indonesian Financial Service Authority (OJK). It imposes three different selection processes for the JII. Firstly, it eliminates firms that involve in non-sharia compliance businesses. Secondly, it conducts various quantitative screening's standards. These criteria constitute:

a) The total of the interest-bearing loan to the total assets is less than $45 \%$;

b) The total return from interest and other prohibited income to the total revenue is less than $10 \%$;

c) Total debt over market capitalisation and accounts payable over market capitalisation are less than $30 \%$.

Lastly, after obtaining the Sharia-compliant list from earlier screening, it selects the 30 top stocks that the most liquid with the largest last year market capitalisation. Hence, the public listed companies that adhere to the above criteria could be included in the JII (IDX, 2000). The JII's 
calculation method is derived from the 'Market Value Weighted Average Index' utilising Laspeyres formulation below (Japan, 1996):

$\frac{\sum_{i} p_{i t} q_{i 0}}{\sum_{i} p_{i 0} q_{i 0}}$

(Error! No text

\section{of specified style in document..1)}

Where $p_{i t}$ denotes the price and $q_{i 0}$ as quantity.

\subsection{Method Technique}

From the above data, this study has four variables. These are the JII, SBIS rate, $S B I$ rate, and $M 2$. The SBIS and SBI are in their fundamental value while the $J \|$ and $M 2$ are transformed into its natural logarithm form (LN_JII, LN_M2). The LN_Jll is chosen as it reflects the performance of the most liquid sharia compliance stocks return in Indonesian capital market (see. Malini and Jais (2014), and Pranata and Nurzanah (2015)). Then, the SBIS rate is chosen as the primary Islamic monetary instrument in Indonesia (see. Ascarya (2012), and Wahyudi and Sani (2014)). Subsequently, the SBI is elected to describe the conventional monetary variable as implied by Ascarya (2014), Malini and Jais (2014), and Wahyudi and Sani (2014). Lastly, LN_M2 will be employed as it may affect the capital market performance. This fact is supported by findings from Sims (1992), Friedman (1988), and Ibrahim (2001). These variables are endogenous in the VARVECM method $\left(y_{i t}\right)$ as follows:

$$
y_{i t}=L N_{-} J I I_{t}, S B I S_{t}, S B I_{t}, L N_{-} M 2_{t}
$$

This study will utilise the VAR - Vector Error Correction Model (VECM) and Granger causality analysis to answer the research questions. The VARVECM methodology will analyse the positive or negative influence of the Islamic and conventional monetary instruments, along with the stability of sharia compliance performance stocks in the Jll during the shock. Additionally, Granger causality will look at the correlation between variables in the VAR-VECM system.

\subsection{Empirical Model}

The basic VAR equations for this study are as follows:

$$
\begin{aligned}
L N_{-} J I I_{t}= & \beta_{10}+\sum_{k=1}^{K} \beta_{11} L N_{-} J I I_{t-k}+\sum_{k=1}^{K} \alpha_{12} S B I S_{t-k}+ \\
& \sum_{k=1}^{K} \gamma_{13} S B I_{t-k}+\sum_{k=1}^{K} \delta_{14} L N_{-} M 2_{t-k}+\mu_{1 t}
\end{aligned}
$$




$$
\begin{gathered}
S B I S_{t}=\beta_{20}+\sum_{k=1}^{K} \beta_{21} L N_{-} J I I_{t-k}+\sum_{k=1}^{K} \alpha_{22} S B I S_{t-k}+\sum_{k=1}^{K} \gamma_{23} S B I_{t-k}+ \\
\sum_{k=1}^{K} \delta_{24} L N_{-} M 2_{t-k}+\mu_{2 t} \\
S B I_{t}=\beta_{30}+\sum_{k=1}^{K} \beta_{31} L N_{-} J I I_{t-k}+\sum_{k=1}^{K} \alpha_{32} S B I S_{t-k}+\sum_{k=1}^{K} \gamma_{33} S B I_{t-k}+ \\
\quad \sum_{k=1}^{K} \delta_{34} L N_{-} M 2_{t-k}+\mu_{3 t} \\
L N_{-} M 2_{t}=\beta_{40}+\sum_{k=1}^{K} \beta_{41} L N_{-} J I I_{t-k}+\sum_{k=1}^{K} \alpha_{42} S B I S_{t-k}+ \\
\sum_{k=1}^{K} \gamma_{43} S B I_{t-k}+\sum_{k=1}^{K} \delta_{44} L N_{-} M 2_{t-k}+\mu_{4 t}
\end{gathered}
$$

Where $\beta_{i t}, \alpha_{i t}, \gamma_{i t}, \delta_{i t}$ denotes the estimation parameters of each variable, $\beta_{i 0}$ represent the intercept, and $\mu_{i t}$ as white noise disturbances for each model. The necessary and standard hypothesis tests for the VAR-VECM method also executed in this study. Furthermore, as the cointegration present and all variables are stationary at first difference, the model can be expanded into the VECM. The VECM equations adapted for this study with the occurrence of cointegration are as follows:

$$
\begin{gathered}
\Delta L N_{-} J I I_{t}=\mu_{10}+\Pi_{11} E C T_{t-1}+\sum_{k=1}^{K} \beta_{12} L N_{-} J I I_{t-k}+\sum_{k=1}^{K} \alpha_{13} S B I S_{t-k}+ \\
\sum_{k=1}^{K} \gamma_{14} S B I_{t-k}+\sum_{k=1}^{K} \delta_{15} L N_{-} M 2_{t-k}+\varepsilon_{1 t} \\
\Delta S B I S_{t}=\mu_{20}+\Pi_{21} E C T_{t-1}+\sum_{k=1}^{K} \beta_{22} L N_{-} J I I_{t-k}+\sum_{k=1}^{K} \alpha_{23} S B I S_{t-k}+ \\
\sum_{k=1}^{K} \gamma_{24} S B I_{t-k}+\sum_{k=1}^{K} \delta_{25} L N_{-} M 2_{t-k}+\varepsilon_{2 t} \\
\Delta S B I_{t}=\mu_{30}+\Pi_{31} E C T_{t-1}+\sum_{k=1}^{K} \beta_{32} L N_{-} J I I_{t-k}+\sum_{k=1}^{K} \alpha_{33} S B I S_{t-k}+ \\
\sum_{k=1}^{K} \gamma_{34} S B I_{t-k}+\sum_{k=1}^{K} \delta_{35} L N_{-} M 2_{t-k}+\varepsilon_{3 t} \\
\Delta L N_{-} M 2_{t}=\mu_{40}+\Pi_{41} E C T_{t-1}+\sum_{k=1}^{K} \beta_{42} L N_{-} J I I_{t-k}+\sum_{k=1}^{K} \alpha_{43} S B I S_{t-k}+ \\
\quad \sum_{k=1}^{K} \gamma_{44} S B I_{t-k}+\sum_{k=1}^{K} \delta_{45} L N_{-} M 2_{t-k}+\varepsilon_{4 t} \\
\quad \text { (Error! No text of specified style in document..3) }
\end{gathered}
$$

where $\Pi_{i 1}$ of each model represent the coefficient of the ECT and $\varepsilon_{i t}$ indicates the residual of $V E C M$ equations.

\section{RESULT AND ANALYSIS}

\subsection{The Results of VAR-Related Tests}

This study employs four endogenous variables in the VAR-VECM model as describes in the previous section. The Jarque-Bera normality test of every variable indicates that none of the variables is normally distributed although having lower means. Moreover, they possess various trends across the 
period of analysis at the level data. These trends are as depicted in Figure below.

LN_JII

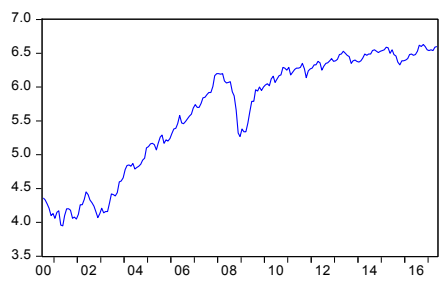

SBIS

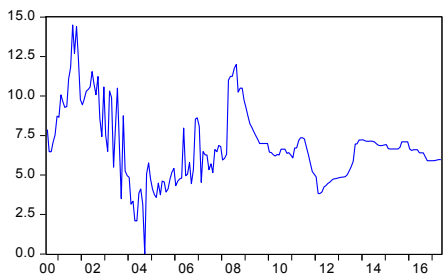

$\mathrm{SBI}$

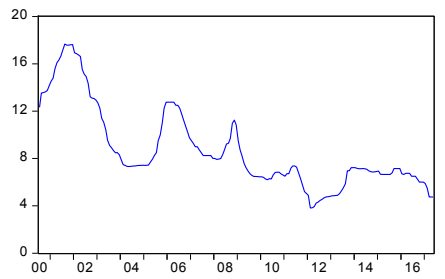

LN_M2

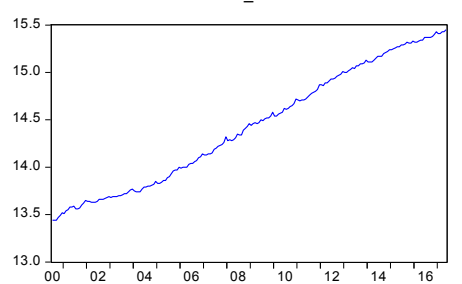

Figure 3.

\section{Level Data of All Variables}

These variables portray trends with different tendencies. The upwards slope occurs within LN_Jll and LN_M2, while SBI signals downward slope and SBIS is more volatile and has a decreasing trend in the long-term. The VAR-VECM and Granger necessitate the variables to be stationary rather than increasing movement. Hence, it requires first differencing to produce stationary variables, which is portrayed in Figure below:

D(LN_JII) Residuals

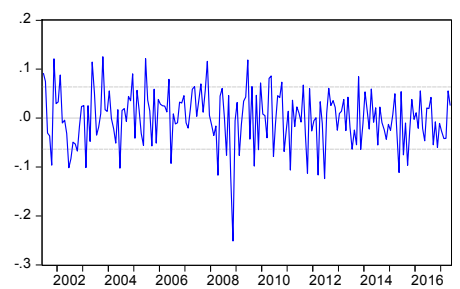

$\mathrm{D}(\mathrm{SBI})$ Residuals

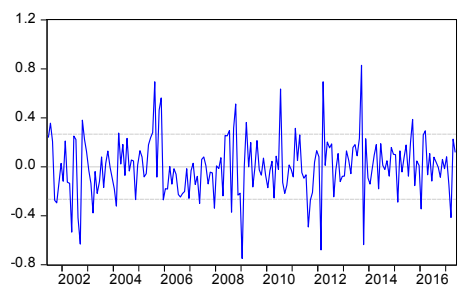

D(SBIS) Residuals
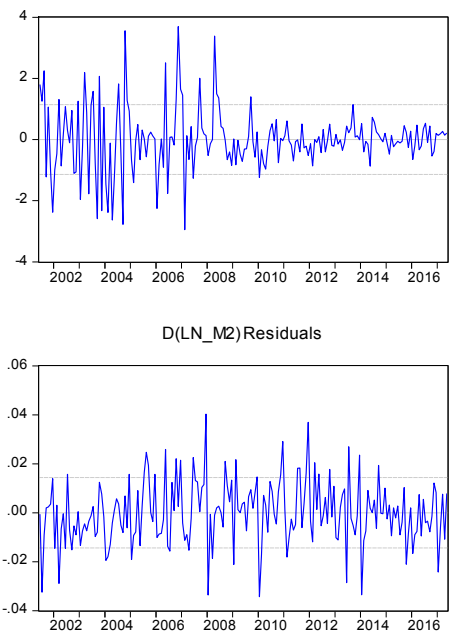

Figure 4. 


\section{First Difference Data of All Variables}

The Figure 4. above shows that the trends that are transformed indicate the data's movement into reversion to the mean states and the presence of the white noise. Thus, the next analysis can be resumed. Then, the unit root tests are conducted to analyse the further possibilities of cointegration among variables. The test results are as portrayed below.

Table 4. (a)

Unit Root Test with Intercept, and Trend and Intercept

\begin{tabular}{|c|c|c|c|c|c|}
\hline & \multirow{2}{*}{$\begin{array}{c}\text { Variable/ } \\
\text { Unit Root Test }\end{array}$} & \multicolumn{2}{|c|}{ Ln_JlI } & \multicolumn{2}{|r|}{ SBIS } \\
\hline & & Inter-cept & $\begin{array}{c}\text { Trend/ } \\
\text { Intercept }\end{array}$ & Inter-cept & Trend/ Intercept \\
\hline \multirow{3}{*}{ 嵅 } & Level & -1.11 & -1.89 & -2.23 & -2.38 \\
\hline & 1st Difference & $-11.26^{* * *}$ & $-11.25^{\star * *}$ & $-15.90 * * *$ & $-15.86^{* * *}$ \\
\hline & 2nd Difference & & & & \\
\hline \multirow{2}{*}{$\frac{0}{2}$} & Level & -1.04 & -1.89 & $-2.70^{*}$ & $-2.82^{*}$ \\
\hline & 1st Difference & $-11.29 * * *$ & $-11.28^{* * *}$ & $-19.26^{* * *}$ & $-19.21 * * *$ \\
\hline \multirow{2}{*}{\multicolumn{2}{|c|}{$\begin{array}{c}\text { Variable/ } \\
\text { Unit Root Test }\end{array}$}} & \multicolumn{2}{|c|}{ Ln_JlI } & \multicolumn{2}{|r|}{ SBIS } \\
\hline & & Inter-cept & $\begin{array}{c}\text { Trend/ } \\
\text { Intercept }\end{array}$ & Inter-cept & Trend/ Intercept \\
\hline$\frac{n}{\frac{n}{2}}$ & $\begin{array}{l}\text { Level } \\
\text { 1st Difference }\end{array}$ & $\begin{array}{l}1.63^{*} \\
0.09 * \star *\end{array}$ & $\begin{array}{l}0.33 \\
0.06^{\star \star *}\end{array}$ & $\begin{array}{l}21.38 \\
0.03^{* * *}\end{array}$ & $\begin{array}{l}8.58 \\
0.03 * \star *\end{array}$ \\
\hline \multicolumn{2}{|c|}{ Conclusion } & l(1) & & I(1) & \\
\hline
\end{tabular}

Table 4.(b)

Unit Root Test with Intercept, and Trend and Intercept

\begin{tabular}{|c|c|c|c|c|c|}
\hline & \multirow{2}{*}{$\begin{array}{c}\text { Variable/ } \\
\text { Unit Root Test }\end{array}$} & \multicolumn{2}{|r|}{ SBI } & \multicolumn{2}{|c|}{ Ln_M2 } \\
\hline & & Inter-cept & Trend/ Intercept & Inter-cept & $\begin{array}{c}\text { Trend/ } \\
\text { Intercept }\end{array}$ \\
\hline \multirow{3}{*}{ 荇 } & Level & -1.90 & -2.42 & 0.25 & -2.62 \\
\hline & 1st Difference & $-7.45 * * *$ & $-7.43^{* * *}$ & $-2.79^{*}$ & $-2.82^{\star}$ \\
\hline & 2nd Difference & & & $-11.10 * * *$ & $-11.06 * * *$ \\
\hline \multirow{2}{*}{ 은 } & Level & -1.49 & -2.44 & 0.22 & -1.94 \\
\hline & 1st Difference & $-7.45 * * *$ & $-7.43 * * *$ & $-17.04 * * *$ & $-17.03 * * *$ \\
\hline \multirow{2}{*}{\multicolumn{2}{|c|}{$\begin{array}{c}\text { Variable/ } \\
\text { Unit Root Test }\end{array}$}} & & SBI & \multicolumn{2}{|c|}{ Ln_M2 } \\
\hline & & Inter-cept & Trend/ Intercept & Inter-cept & $\begin{array}{c}\text { Trend/ } \\
\text { Intercept }\end{array}$ \\
\hline$\frac{n}{\frac{n}{y}}$ & ¿ Level & 1.17 & $0.16^{\star}$ & 1.80 & 0.25 \\
\hline
\end{tabular}


1st Difference $\quad 0.04^{* * *} \quad 0.05^{* * *} \quad 0.16^{* * *} \quad 0.14^{* *}$

Conclusion l(1) I(1)

The results of the unit root test above convey that all variables are stationary at first different according to PP and KPSS tests at 5\% significance level. The overall results infer that all four variables from LN_Jll, SBIS, SBI, and LN_M2 are stationary at I(1) and hence the cointegration test in the latter stage could be executed. Coupled with this, the lag optimum for the model is implemented. The results of lag length testing are as described in below Table.

Table 5.

Lag Optimum Test

\begin{tabular}{ccccc}
\hline Lag & \multicolumn{4}{c}{ Information Criteria Result } \\
& FPE & AIC & SC & HQ \\
\hline 0 & $2.20 \mathrm{e}-07$ & -3.98 & -3.91 & -3.95 \\
1 & $1.31 \mathrm{e}-07$ & -4.50 & $-4.16^{*}$ & $-4.36^{\star}$ \\
2 & $1.21 \mathrm{e}-07^{*}$ & $-4.58^{\star}$ & -3.97 & -4.33 \\
3 & $1.27 \mathrm{e}-07$ & -4.53 & -3.65 & -4.17 \\
\hline Notes: ${ }^{*}$ ) denotes selection of lag order from information criterion \\
FPE: Final Prediction Error \\
AlC: Akaike Information Criterion \\
SC: Schwarz Information Criterion \\
HQ: Hannan-Quinn Information Criterion
\end{tabular}

According to the result in the Table above, AIC and FPE denote the lag optimum at 2. Meanwhile, SC and $\mathrm{HQ}$ results are indicating the optimum lag at 1 . The SC is preferable for the larger sample number (Wahyudi \& Sani, 2014). However, the lag 1 suffers the autocorrelation issue from the Serial Correlation LM test in which affecting the models' white noise. Thus, the writer opts for the AIC criteria for the lag optimum to be implemented for further analysis as it does not hold autocorrelation problem. Furthermore, the stability test is imperative for VAR-VECM to have a valid impulse response and variance decomposition outcomes. Hence, this test is performed to satisfy the method's prerequisite. The AR Roots Table results implicate that all modulus is $<1$ that infer the stability of the model. Additionally, the Circle Figure below of the AR also presents the test. 
Inverse Roots of AR Characteristic Polynomial

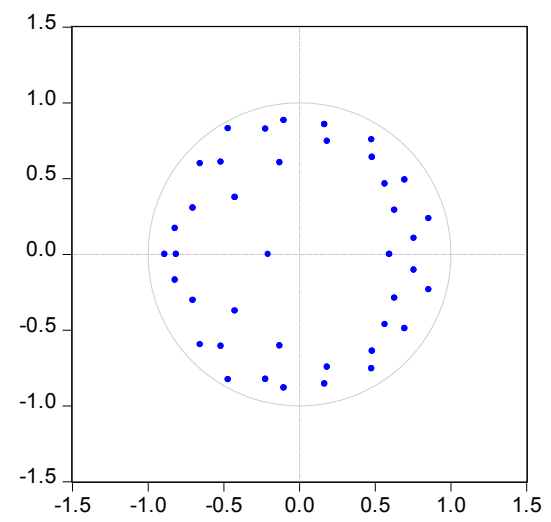

Figure 5 .

AR Graph of VAR Stability

The Figure above strengthens the assertion that this model is stable up to 10 lags. Hence, the selected lag 2 of the VAR will be stable. Then, since all variables are stationary at first different $I(1)$, the cointegration test could be executed, and the result is valid. The Johansen Cointegration test's results are portrayed below.

Table 6 .

Johansen Cointegration Test

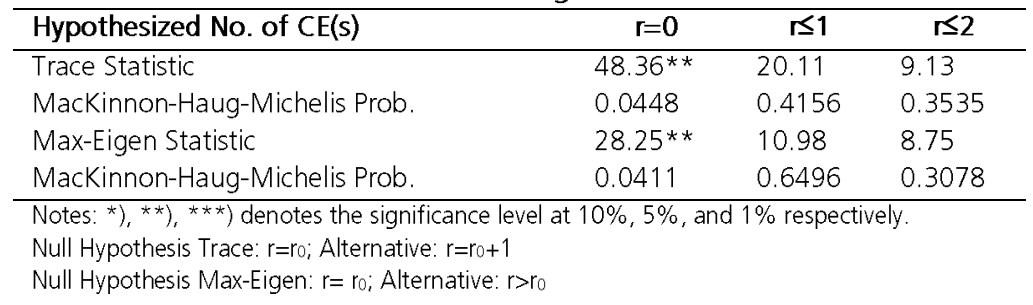

The table above is emanated from the third model of linear deterministic data trend with intercept and no trend in VAR (Eviews, 2017). The model VAR with optimum lag at two becomes $r=k-1=2-1=1$ for the lag intervals choice of cointegration, and resulting in at minimum one cointegration in either the Trace or Max-Eigen statistics. In this study, the theories and previous findings assure the presence of the cointegration between the monetary variables and Islamic capital market. The Table above signifies the rejection of the null hypothesis from the Trace and MaxEigen statistics, which validate the cointegration assumptions of the study at $5 \%$ significance level. To conclude the above VAR-Related test, this study 
operates with several premises. Firstly, all variables are stationary at first difference. Secondly, the lag optimum chosen for the VAR-VECM is at lag 2, which does not suffer autocorrelation and stable. Thirdly, one cointegration is subsisting in the model 3. The following section will discuss the result from the VAR-VECM operation.

\subsection{VECM Results and Interpretation}

As the cointegration presents in the previous Johansen test, this study will employ the VECM to examine the long-term correlation of the monetary variables to the JII. The extension of the VAR model into the VECM is discussed herein together with their results. In the short-run, the VECM results for every variable for $\Delta \mathrm{LN} \_$Jlt equation are shown in below Table.

Table 7.

Short-term VECM Coefficients

\begin{tabular}{|c|c|c|c|}
\hline Variables & Coefficient & $\begin{array}{l}\text { Standard } \\
\text { errors }\end{array}$ & T-Statistics \\
\hline D(LN_JII(-1)) & 0.140 & 0.073 & $1.923^{*}$ \\
\hline$D\left(L N \_J \|(-2)\right)$ & -0.070 & 0.072 & -0.962 \\
\hline$D(S B \mid S(-1))$ & 0.003 & 0.004 & 0.721 \\
\hline$D(S B \mid S(-2))$ & 0.005 & 0.004 & 1.216 \\
\hline $\mathrm{D}(\mathrm{SBI}(-1))$ & -0.053 & 0.017 & $-3.036^{* \star *}$ \\
\hline$D(S B \mid(-2))$ & 0.014 & 0.018 & 0.870 \\
\hline$D\left(L N \_M 2(-1)\right)$ & -0.296 & 0.315 & -0.939 \\
\hline$D\left(L N \_M 2(-2)\right)$ & -0.073 & 0.316 & -0.230 \\
\hline c & 0.013 & 0.007 & 1.820 \\
\hline
\end{tabular}

The results of short-run VECM above apply the t-statistics of the coefficient's significance. These results imply the majority of variables are not statistically significant in influencing the $\Delta \mathrm{LN} \_J \mid l$ in the short-run. The exception occurs for the lag one of the $L N_{-} J \|\left(D\left(L N_{-} J \|(-1)\right)\right)$ and lag one of the $\mathrm{SBI}(\mathrm{D}(\mathrm{SBI}(-1)))$ whereby both variables are statistically significant in affecting the LN_Jll in the short-term at 10\% and $1 \%$ level respectively. The SBI in its lag one induces an adverse effect on the LN_Jll for the short run. This result describes that $1 \%$ increase of the $\mathrm{SBI}$ at lag one will decrease 
the JII's performance for 0.053 points in one lag. This short-term adverse effect of the conventional monetary instrument in the form of interest rate is rejecting the sharia concept. Hence, the injunction of riba has not adhered in the JII case which indicates its dependence on the interest rate in the short-run notwithstanding its prohibition in Islamic principles. This result confirms the previous findings from Ajmi et al. (2014), Malini and Jais (2014), and Pranata and Nurzanah (2015).

Moreover, this result differs with Majid and Yusof's (2009) finding that when interest rate increase, the Muslim investor should invest more in Islamic capital market. Hence, notwithstanding the similar significance correlation with their results, this study varies from its coefficient sign or the effect of the variable. Furthermore, this adverse effect may occur if Bank Indonesia increases the interest rate to stabilise the inflation that eventually affects the Islamic capital market (Wahyudi \& Sani, 2014). Meanwhile, this finding disaffirms the assertion of Hakim and Rashidian (2002), Yosuf and Majid (2007), Wahyudi and Sani (2014), Rana and Akhter (2015), and lastly Bahloul et al. (2017) of interest rate's disconnection. Thus, the disassociation of Islamic capital market system with conventional financial tools is rejected in the short-run and indicates the occurrence of a substitution effect between interest rate and investment. However, this effect will perish eventually. This fact is upheld as per The VECM estimation results for the long-run in the following Table.

Table 8.

Long-term VECM Cointegrated Coefficients

\begin{tabular}{lccc}
\hline \multicolumn{1}{c}{ Variables } & Coefficient & Standard errors & T-Statistics \\
\hline SBIS(-1) & 1.485 & 0.413 & $3.594^{* * *}$ \\
SBI(-1) & -0.296 & 0.377 & -0.787 \\
LN_M2(-1) & -0.680 & 1.616 & -0.421 \\
ECT & -0.006 & 0.002 & $-3.247^{* * *}$ \\
C & -3.360 & & \\
\hline
\end{tabular}

Notes: $\left.\left.{ }^{\star}\right),{ }^{* *}\right),{ }^{* \star}$ ) denotes the significance level at $10 \%, 5 \%$, and $1 \%$ respectively

The results of long-run VECM above apply the t-statistics for the coefficient's significance. The results in Table above imply that SBI and $L N \_M 2$ are not statistically significant in affecting the $\triangle \mathrm{LN} \_J l$ at the longrun of the VECM. Hence, the result of LN_M2 ensuring the rejection of the assumption where the monetary base should negative and significantly 
affecting the Islamic capital market. This result affirms with the research conducted by Lee (1992), Maysami and Koh (2000), Durham (2003), Yusof and Majid (2007), and Abugri (2008). Meanwhile, this finding contravenes with Fama (1981), James et al. (1985), and Rahman et al. (2009) whereas the $M 2$ has an adverse influence on conventional or Islamic capital market.

Additionally, the subsequent result of SBI denotes the acceptance of the theory that is indicating the negation of the interest rate's effect towards sharia compliance stocks' performance, which represented by the $\triangle \mathrm{LN} \_\mathrm{Jll}$ in this case. This outcome is consistent with sharia principle's application on interest rate's injunction although it is occurred in the longterm as such. This finding upholds previous studies from Hakim and Rashidian (2002), Yosuf and Majid (2007), Wahyudi and Sani (2014), Rana and Akhter (2015), and Bahloul et al. (2017). Then, this long-run circumstance opposes the hypothesis from Majid and Yusof (2009), Ajmi et al. (2014), Malini and Jais (2014), and recently Pranata and Nurzanah (2015). Meanwhile, the SBIS is proven to be positive and statistically significant to affect the $\triangle \mathrm{LN} \_\mathrm{Jl}$ in the long-run period.

This finding leads to the acceptance of the assumption that denotes the positive impact of Islamic monetary instrument to the Islamic stock market. The coefficient of the SBIS is positive and significance at $1 \%$ level that indicates the strong effect of the SBIS rate towards the $\triangle L N \_J I I$. The result implies the increase of the SBIS rate for $1 \%$ will ultimately improve the Jll's performance by 1.48 point in the long-term. This result sustains the Islamic monetary transmission channel concept in Indonesia, whereby the SBIS rate will affect the PUAS that eventually influence the financial asset price, including sharia compliance stocks. The finding refutes Ascarya's (2012) argument that the SBIS's effect is discontinued at the PUAS, and upholds the notion from Wahyudi and Sani (2014). Additionally, the Error Correction Term (ECT), which indicates the presence of the long-term cointegration in the model, is also statistically significant at $1 \%$ level of significance. This result signifies the $0.6 \%$ speed adjustment of disequilibrium is adjusted by all variables every year.

\subsection{Granger Causality}

The Granger causality analysis could be performed providing the stationarity of variables at first difference (Ajmi, Hammoudeh, Nguyen, \& Sarafrazi, 2014), and a cointegration occurs within models (Wahyudi \& Sani, 2014). To assess the causation of the operation variables in the short- 
run, Granger Causality (Wald Test) is conducted. The results of this test are as depicted below:

Table 9.

Granger Causality and Error Correction Term (ECT)

\begin{tabular}{|c|c|c|c|c|c|}
\hline \multirow{2}{*}{$\begin{array}{c}\text { Dependent } \\
\text { Variables }\end{array}$} & \multicolumn{4}{|c|}{ Causality Sources } & \multirow[b]{2}{*}{ ECT } \\
\hline & $\mathrm{D}\left(\mathrm{LN} \_\mathrm{JII}\right)$ & $\mathrm{D}(\mathrm{SBIS})$ & $\mathrm{D}(\mathrm{SBI})$ & $\mathrm{D}\left(\mathrm{LN} \_\mathrm{M} 2\right)$ & \\
\hline D(LN_JII) & . & $\begin{array}{l}1.58 \\
(0.4537)\end{array}$ & $\begin{array}{l}10.34^{* * *} \\
(0.0057)\end{array}$ & $\begin{array}{l}0.88 \\
(0.6427)\end{array}$ & $\begin{array}{l}-0.0062^{* * *} \\
(0.00190)\end{array}$ \\
\hline$D(S B \mid S)$ & $\begin{array}{l}0.07 \\
(0.9655)\end{array}$ & . & $\begin{array}{l}7.29^{* * *} \\
(0.0261)\end{array}$ & $\begin{array}{l}1.85 \\
(0.3969)\end{array}$ & $\begin{array}{l}-0.0739 * * \\
(0.03197)\end{array}$ \\
\hline $\mathrm{D}(\mathrm{SBI})$ & $\begin{array}{l}1.35 \\
(0.5090)\end{array}$ & $\begin{array}{l}6.83^{* * *} \\
(0.0328)\end{array}$ & & $\begin{array}{l}0.76 \\
(0.6828)\end{array}$ & $\begin{array}{l}-0.0101 \\
(0.00802)\end{array}$ \\
\hline $\mathrm{D}\left(\mathrm{LN} \_\mathrm{M} 2\right)$ & $\begin{array}{l}2.15 \\
(0.3418)\end{array}$ & $\begin{array}{l}2.12 \\
(0.3467)\end{array}$ & $\begin{array}{l}0.65 \\
(0.7212)\end{array}$ & . & $\begin{array}{l}-0.0001 \\
(0.00044)\end{array}$ \\
\hline
\end{tabular}

Note: the figure in the parentheses reflect the standard errors of ECT and the p-value of VEC Granger Causality Test. The rejection of significance level at $1 \%, 5 \%$, and $10 \%$ is portrayed by $* * *$ ), **), and

*) respectively. Granger causality Null hypothesis: the causality source does not Granger cause Dependent Variables.

The results in Table above show the output of the Granger causality of the Wald Test, which infers several implications from its testing values. Firstly, the short run SBI is statistically significant to Granger cause the LN_Jll that consistent with the previous result of the VECM model. The negative and significant short-run effect to the JII subsist and defend the theory. This causality ratifies findings of Ajmi et al. (2014), Wahyudi and Sani (2014), Malini and Jais (2014), and Pranata and Nurzanah (2015). Nonetheless, the SBI only unidirectionally causes the JII as implied in Ajmi et al. (2014), while the short-run causality affirms the finding of the SBI's influence to the JII pre-2008 (Wahyudi \& Sani, 2014). The causality of the SBI occurs due to its influences in the property sector's stocks in Indonesia. This industry is the major constituent of the JII's portfolio and supported by the fact that it had an enormous expansion that amounted 186.3 Trillion Rupiah. However, this trend diminished after 2008 (Kompas, 2008). Furthermore, in the $\Delta \mathrm{LN} \_J l t$ equation, the short-run causality of the SBIS and money supply are nonexistent, which affirms Ascarya's (2012) and Pranata and Nurzanah (2015) findings. It corroborates Ascarya's argument of discontinuation of the SBIS immediate effect on the financial market. Hence, the short-run causality result is upholding the association of Islamic market with the conventional financial regime (Ajmi, Hammoudeh, Nguyen, \& Sarafrazi, 2014), persisting the notion of interest rate effect to the sharia compliance stocks due to their presence in the parallel economy with the conventional system (Malini \& Jais, 2014). 
Secondly, this test also points out the occurrence of bi-directional causality between the SBIS and SBI, which indicates the correlation among these two monetary variables. These two variables are statistically significant at $1 \%$ level on causing each other in $\triangle \mathrm{SBISt}$ and $\triangle \mathrm{SBIt}$ 's equation. This result verifies Wahyudi and Sani's (2014) research of the same occurrence, whereby bi-directional causation perseveres on both variables in full period. The finding substantiates the benchmarking issues of Islamic and conventional policy rates which appear in Indonesia besides Malaysia (Chong \& Liu, 2009). Hence, the Islamic and conventional monetary instruments are affecting each other, which contravenes the sharia tenets. Additionally, the long-term ECTs are only statistically significant in $\Delta \mathrm{LN} \_$Jllt and $\triangle \mathrm{SB} I S t$ models that indicate long-term adjustments in both equations. Then, the next section will investigate the stability of the sharia compliance stocks in the Jll through the innovation accounting mechanisms as suggested by Lee (1992).

\subsection{Impulse Response and Variance Decomposition Analysis}

The impulse response function (IRF) and forecast error of variance decomposition (FEVD) are conducted to observe the long-run response of the variable LN_Jll during the occurrence of the shock, how long it is stabilised following the impulse effect and the total contribution of each variable on the shock. Firstly, the writer examines the shocks in three monetary variables from SBIS, SBI, and LN_M2. Then, the LN_JII will respond towards these impulses in 60 periods. The impact of these shocks is as described in below figure. 
Response to Cholesky One S.D. Innovations

Response of LN_JII to SBIS
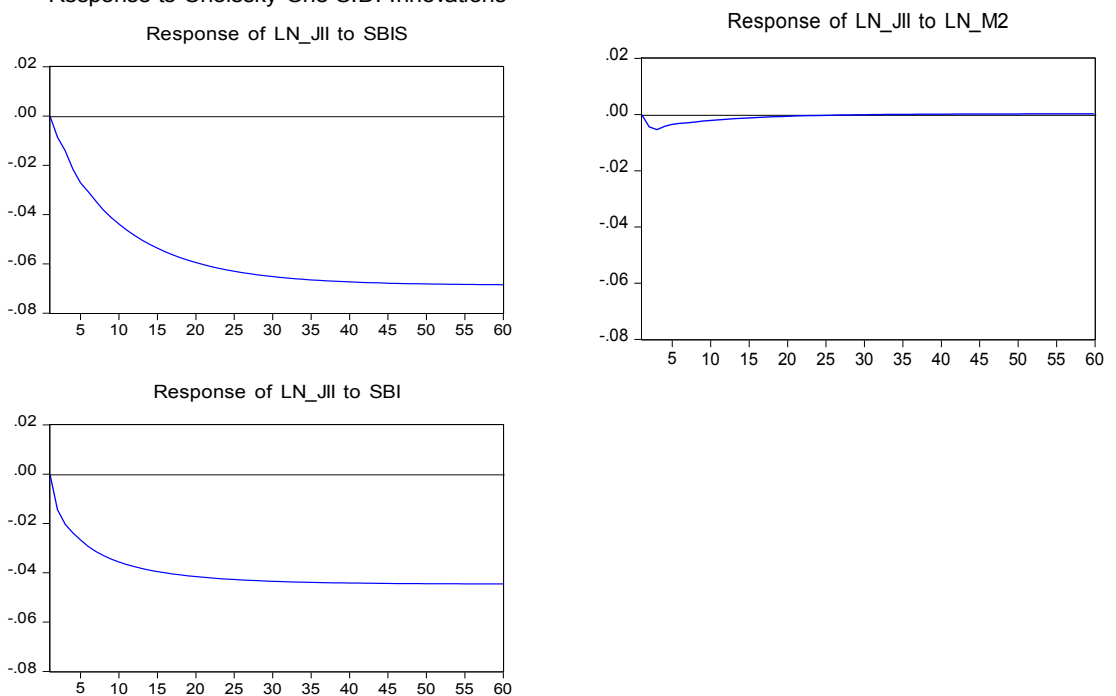

Figure 6.

Impulse Response Function of VECM

The Figure above conveys several implications. Firstly, the shock in SBIS will lead to a continuous and negative response of the LN_Jll in longrun or for 40 periods. Moreover, this trend seems to descend with lower negative response continuously. Hence, the shock in Islamic monetary variable will induce the incessant negative response of the JII if the shock occurs within the SBIS. The first impulse result upholds the occurrence of the Islamic monetary transmission mechanism (Ascarya, 2012). This negative and continuous trend after the shock is emanated from the fact that both variables cointegrated in the long-run equation, which implies the monetary agent should carefully adjust the Islamic policy rates to have a minimum response to the Islamic capital market. Secondly, the shock in SBI variable is also directing the negative response to the LN_Jll for 19 periods, and the LN_Jll will remain negative and stable following this phase. The shorter reaction to the SBI from the $L N \_J l l$ validates its short-run effect to the sharia compliance stock market in Indonesia (Pranata \& Nurzanah, 2015). Lastly, due to the insignificance of the M2 variable to the JII and no cointegration present in its equation, the shock in this variable will cause a negative response for ten periods in which the shortest one. The LN_Jll will stable and revert to its mean or former condition accordingly and consistent with Yusof and Majid (2007) and Abugri (2008). Additionally, the FEVD denotes the contribution of every variable in explaining the shock response of the LN_JII. The results of the FEVD is portrayed below. 


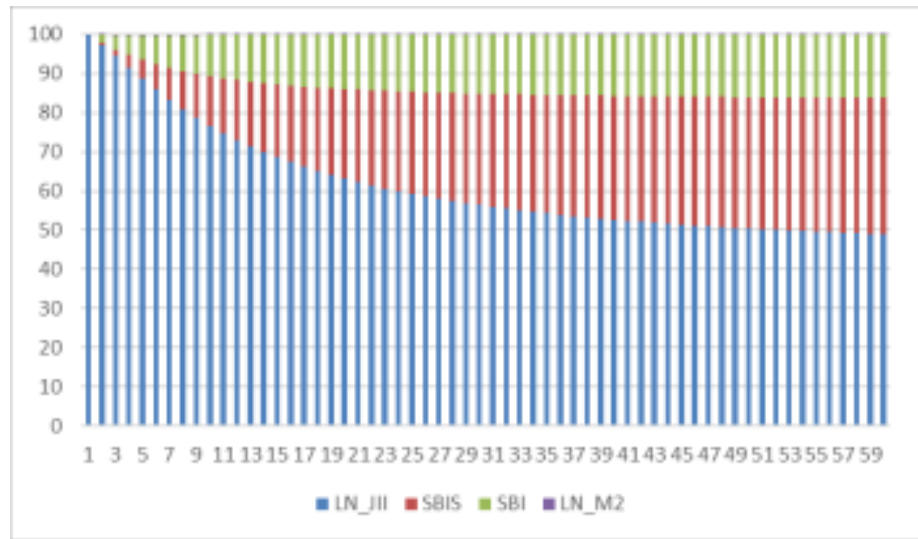

Figure 7.

Forecast Error Variance Decomposition of VECM

The Figure above implies the SBIS variable contributes the most in explaining the LN_Jll after the LN_Jll's shock contribution, followed by SBI and LN_M2 which has the least contribution to the LN_JII. SBIS variable accounts for $34.85 \%$ of its negative contribution to the LN_Jll's shock. Hence, this Islamic monetary instrument should be primarily considered in the transmission mechanism of monetary policy through the Islamic capital market channel, as it dominantly affecting the Jll over the long-term. Subsequently, the SBI variable presents a negative contribution to the LN_JII for $16.2 \%$. Notwithstanding its less contribution, this conventional monetary instrument should be deemed to prevent the short-run negative influence on the Islamic capital market in Indonesia as explained formerly. These two variables are the significant contribution towards the shock in the JII and related to this study findings. Lastly, the LN_M2 only contributes negatively to the $L N \_J l l$ for $0.02 \%$. Hence, this variable should be taken into lesser attention in transmitting the monetary policies for its small contribution to the JII. Nevertheless, the JII's volatility should be considered as it contains information regarding the LN_M2 or monetary base.

\section{CONCLUSION}

The implementation of Islamic principle within the capital market diverges the Islamic capital market from the mainstream market. This distinct market offers diversity and portfolio alternatives for the investors that willing to adhere to sharia tenets in shares' trading. However, several economic variables are affecting their performance, and it is not limited to the shariacompliance ones but also the conventional instruments. This reality is 
derived from the fact that the Islamic capital market operates within the conventional financial regime, which transpires in several Islamic markets including Indonesia. The primary variables that correlate with the capital market befall within monetary instruments. The alteration of these tools may affect the market's performance, in which elucidated as monetary transmission mechanism through the capital market channel.

The transmission processes of monetary policies and their effects towards the performance of the Islamic capital market ensuring various consequences. Hence, this study aims at evaluating the influence of the Islamic and conventional monetary variables to this market's performance by looking at Indonesia case. Furthermore, this research evaluates the reaction of this market in the event of the shocks in monetary variables. The Jakarta Islamic Index's (JII) values represent the Islamic capital market performance in Indonesia, whereas the SBI, the SBIS, and the monetary base (M2) denote the Islamic, conventional, and neutral monetary instruments correspondingly. This paper demonstrates monthly value examination of these policies and the monthly closing value of the $\mathrm{Jl}$ between July 2000 and May 2017 within VAR-VECM and Granger Causality assessments.

These measurements infer different result vis-à-vis the theory. The short-term outcome signifies the dependency of the JII's performance with the domestic interest rate or SBI rate regardless of its prohibition in Islamic principles. This rate induces negative and significant impact to the JII and reflecting the substitution effect in the market. Contrariwise, the domestic Islamic policy rate or SBIS rate is positively affecting the JII's value although it occurs in the long-run. This finding accentuates the Islamic monetary policy transmission mechanism concept in Indonesia, which argues the continuation of SBIS effect in the financial market. Nonetheless, the M2 does not indicate any significant influence on the $\mathrm{JII}$ notwithstanding its significance in previous studies.

The next discoveries from Granger Causality justify several notions. The causality result affirms the short-run effect of the interest rate to the Indonesia's Islamic capital market, and it perishes eventually in the longer period. This causality outcome also verifies the benchmarking problem between the Islamic and conventional policy rates, in which both instruments are Granger cause each other. Moreover, although the M2 is not influencing the $\mathrm{Jl}$, the $\mathrm{Jl}$ seems to affect the M2.

Then, the stability analysis from the IRF and FEVD convey the responses of the Jll to the monetary instruments. Firstly, due to the cointegration of the $\mathrm{JII}$ and SBIS, the shock in this variable produces 
negative and continuous consequences for the Jll over the long-run. Secondly, the impulse in the SBI trigger adverse reaction in 19 periods and then the Islamic market will subsequently stabilise. Lastly, as no correlation subsists between the $\mathrm{M} 2$ and the $\mathrm{JII}$, the shock of this variable is showing negative impact in the shortest period as such. Additionally, the FEVD outcome construed the SBIS is largely contributing the shocks in the $\mathrm{JI}$, followed by the $\mathrm{SBI}$ and the $\mathrm{M} 2$ respectively. Therefore, in transmitting the Islamic monetary policy through the Islamic capital market channel in Indonesia, the central bank should carefully consider the SBIS first and then the SBI to prevent alarming negative impulse in the market.

Nevertheless, this study comprises several limitations, and the writer suggests some advancements for more robust analysis in the future. The research is mainly focusing on the primary monetary variables effect rather than the comprehensive monetary tools due to the data limitation issue. Therefore, further analysis should comprise more features of monetary policy to having the comprehensiveness of investigation. Secondly, this study only looks at one country analysis while other countries may have the identical dual monetary policy. Thus, future research can be conducted by comparing different jurisprudences that implement the dual monetary regime of Islamic and conventional to have a complete understanding of the effect of monetary policies on Islamic capital market. Finally, this paper excludes other macroeconomic variables. Hence, the combination of macro and monetary aspects could be executed in future research. 


\section{REFERENCES}

Abugri, B. A. (2008). Empirical relationship between macroeconomic volatility and stock returns: Evidence from Latin American markets. International Review of Financial Analysis, 17(2), 396-410. https://doi.org/10.1016/j.irfa.2006.09.002.

Ajmi, A. N., Hammoudeh, S., Nguyen, D. K., \& Sarafrazi, S. (2014). How strong are the causal relationships between Islamic stock markets and conventional financial systems? Evidence from linear and nonlinear tests. Journal of International Financial Markets, Institutions and Money, 28(1),

213-227. https://doi.org/10.1016/j.intfin.2013.11.004.

Albaity, M., \& Ahmad, R. (2008). Performance of Syariah and Composite Indices: Evidence From Bursa Malaysia. Asian Acaaemy of Management Journal of Accounting and Finance, 4(1), 23-43.

Ascarya. (2012). Transmission Channel and Effectiveness of Dual Monetary Policy in Indonesia. Bulletin of Monetary Economics and Banking, (January), 269-298.

Ascarya. (2014). Monetary Policy Transmission Mechanism Under Dual Financial System in Inonesia: Interest-Profit Channel. International Journal of Economics, Management and Accounting, 1(1), 1-32.

Askari, H., Iqbal, Z., \& Mirakhor, A. (2015). Introduction to Islamic Economics (1st ed.). Singapore: John Wiley \& Sons Singapore Pte. Ltd.

Bahloul, S., Mroua, M., \& Naifar, N. (2017). The impact of macroeconomic and conventional stock market variables on Islamic index returns under regime switching. Borsa Istanbul Review, 17(1), 62-74. https://doi.org/10.1016/j.bir.2016.09.003.

Bank Indonesia. (2017). Monetary: Bank Indonesia. Retrieved July 22, 2017, from http://www.bi.go.id/en/moneter/Contents/Default.aspx.

Chapra, M. U. (1985). Towards a Just Monetary System. Leicester: The Islamic Foundation.

Chong, B. S., \& Liu, M. H. (2009). Islamic banking: Interest-free or interestbased? Pacific Basin Finance Journal, 17(1), 125-144. https://doi.org/10.1016/j.pacfin.2007.12.003.

Durham, J. B. (2003). Monetary Policy and Stock Price Returns. Financial 
Analysts Journai, 5S(4), 26-35.

Eviews. (2017). User's Guide: Multiple Equation Analysis: Vector Autoregression and Error Correction Models. Retrieved July 30, 2017, from http://www.eviews.com/help/helpintro.html\#page/content\%2FVARViews_and_Procs_of_a_VAR.html\%23ww256423.

Fama, E. F. (1981). Stock Returns, Real Activity, Inflation, and Money. The American Economic Review, 71(4), 545-565.

Fama, E. F., \& Gibbons, M. R. (1982). Inflation, Real Returns, and Capital Investment. Journal of Monetary Economics, 9, 297-323.

Fama, E. F., \& Schwert, G. W. (1977). Asset Returns and Inflation. Journal of Financial Economics 5, 5, 115-146.

Fisher, I. (1896). Appreciation and Interest. Publications of the American Economic Association, 11(4), 1-98. Retrieved from http://www.jstor.org/stable/2485877.

Friedman, M. (1988). Money and the Stock Market. Journal of Political Economy, 9E(2), 221-245. Retrieved from http://www.jstor.org/stable/1833107.

Geske, R., \& Roll, R. (1983). The Fiscal and Monetary Linkage Between Stock Returns and Inflation. The Journal of Finance, 38(1), 1-33. Retrieved from http://www.jstor.org/stable/1833107.

Hakim, S., \& Rashidian, M. (2002). Risk \& Return of Islamic Stock Market Indexes. 9th Economic Research Forum Annual Meetings Sharjah $U A E_{1} \quad(2), \quad 26-28 . \quad$ Retrieved from http://www. iefpedia.com/english/wp-content/uploads/2009/09/RiskReturn-of-Islamic-Stock-Market-Indexes.pdf.

Hojat, S. (2015). The Impact of Monetary Policy On the Stock Market. Walden University.

Hooker, M. A. (2004). Macroeconomic factors and emerging market equity returns: A Bayesian model selection approach. Emerging Markets Review, 5(4), 379-387. https://doi.org/10.1016/j.ememar.2004.09.001.

Ibrahim, M. H. (2001). Monetary Shocks and Stock Return in an Emerging Market: a VAR Analysis. Savings and Development, 25(4), 439-456. Retrieved from http://www.jstor.org/stable/25830775. 
IDX. (2000). Jakarta Islamic Index. Retrieved July 20, 2017, from http://www.idx.co.id/enus/home/productandservices/sharia/shariastockindex.aspx.

Ismail, A. G. (2010). Money, Islamic Banks and the real Economy. Singapore: Cengage Learning Asia Pte Ltd.

ISRA. (2012). Islamic Financial System: Principles and Operation (1st ed.). Kuala Lumpur: International Shariah Research Academy for Islamic Finance.

James, C., Koreisha, S., \& Partch, M. (1985). A VARMA Analysis of the Causal Relations Among Stock Returns, Real Output, and Nominal Interest Rates. The Journal of Finance, 40(5), 1375-1384. Retrieved from http://Www.jstor.org/stable/2328119.

Japan, S. B. of. (1996). Q\&A about the Consumer Price Index. Retrieved August 7, 2017, from http://www.stat.go.jp/english/data/cpi/1587.htm.

Kompas. (2008). Bisnis Properti Sudah Kebal Krisis. Retrieved August 10, 2017, from

http://properti.kompas.com/read/2008/10/23/10373152/bisnis.prope rti.sudah.kebal.krisis.

Krasicka, O., \& Novak, S. (2012). What's in It for Me? A Primer on Differences between Islamic and Conventional Finance in Malaysia. IMF Working Paper, 12(151), 22. https://doi.org/10.5089/9781475504224.001.

Lee, B.-S. (1992). Causal Relations Among Stock Returns, Interest Rates, Real Activity, and Inflation. The Journal of Finance, 47/(4), 1591-1603. Retrieved from http://www.jstor.org/stable/2328955.

Majid, M. S. A., \& Yusof, R. M. (2009). Long-run relationship between Islamic stock returns and macroeconomic variables. Humanomics, 25(2), 127-141. https://doi.org/10.1108/08288660910964193.

Malini, H., \& Jais, M. (2014). The Volatility of Indonesia Shari ' ah Capital Market Stock Price Toward Macro Economics Variable. Indonesian Capital Market Review, 6(2), 63-72. Retrieved from http://journal.ui.ac.id/index.php/icmr/article/download/3588/2854.

Maysami, R. C., \& Koh, T. S. (2000). A vector error correction model of the Singapore stock market. International Review of Economics and Finance, $\quad 9(1), \quad 79-96 . \quad h t t p s: / / d o i . o r g / 10.1016 / 51059-$ 0560(99)00042-8. 
Mishkin, F. S. (2004). The Economics of Money, Banking, and Financial Markets (1st ed.). Boston: Harlow: Addison-Wesley.

Modigliani, F. (1971). Monetary Folicy and Consumption: Linkages via Interest Rate and Wealth Effects in the FMP Mode.. The Federal Reserve Bank of Boston Conference Series. Massachusetts.

Pranata, N., \& Nurzanah. (2015). Conventional and Islamic Indices in Indonesia: A Comparison on Performance, Volatility, and The Determinants. Indonesian Capital Market Review, 7(2), 113-127.

Rab, H. (2006). Economic Justice in Islam (1st ed.). Kuala Lumpur: A.S. Noordeen.

Rahman, A. A., Sidek, N. Z. M., \& Tafri, F. H. (2009). Macroeconomic determinants of Malaysian stock market. African Journal of Business Management, 3(3), 95-106.

Rana, M. E., \& Akhter, W. (2015). Performance of Islamic and conventional stock indices: empirical evidence from an emerging economy. Financial Innovation, 1(1), 15. https://doi.org/10.1186/s40854-0150016-3.

Reuters, T. (2016). State of The Global Islamic Economy Report. Dubai.

Reuters, T. (2017). EIKON Database. New York.

Rigobon, R., \& Sack, B. (2003). Measuring the Reaction of Monetary Policy to the Stock Market. The Quarterly Journal of Economics, 118(2), 639669. Retrieved from http://www.jstor.org/stable/25053916.

Sims, C. A. (1992). Interpreting the macroeconomic time series facts-The effects of monetary policy. European Economic Review, 36(1992), 975-1011. https://doi.org/10.1016/0014-2921(92)90042-U.

Sukmana, R., \& Kassim, S. H. (2010). Roles of the Islamic Banks in the Monetary Transmission Process in Malaysia. International Journal of Islamic and Middle Eastern Finance and Management, 3(1), 7-19. https://doi.org/10.1108/17538391011033834.

Thorbecke, W. (1997). On Stock Market Returns and Monetary Policy. The Journal of Finance, 52(2), 635-654. Retrieved from http://www.jstor.org/stable/2329493.

Tobin, J. (1969). A General Equilibrium Approach To Monetary Theory. Journal of Money, Credit and Banking, 1(1), 15-29. Retrieved from http://www.jstor.org/stable/1991374. 
Uthman, U. A. (2005). Money, Interest and an Alternative Macroeconomic System. In Studies in Islamic Economics in the 21st Century (pp. 215231). Kuala Lumpur: Kulliyah of Economics and Management Sciences-International Islamic University Malaysia.

Wahyudi, I., \& Sani, A. G. (2014). Interdependence between Islamic capital market and money market: Evidence from Indonesia. Borsa Istanbul Review, 14(1), 32-47. https://doi.org/10.1016/j.bir.2013.11.001.

Wulandari, D. (2014). Pengaruh Beberapa Variabel Moneter Terhadap Harga Saham di Lima Negara Asean. Jurnal Ekonomi Kuantitatif Terapan, $7(2), 183-191$.

Yusof, R. M., \& Majid, M. S. A. (2007). Stock Market Volatility Transmission in Malaysia: Islamic Versus Conventional Stock Market. J.KAU: Islamic Econ., 2C(2), 17-35. 
This page is intentionally left blank 